\title{
Development and Reflection on Early Childhood Education in U.S. Higher Schools
}

\section{Shangwei Li}

\begin{abstract}
Early childhood education at higher schools is a type of education to train early childhood teachers for children $0-8$ years old that have developed very quickly and made a great progress in the United States of America. The paper is to introduce the developmental status and features of early childhood education at the U.S. higher schools. Investigation shows that there are at least 228 colleges and universities with early childhood education major, focusing on "higher educational level", "various major fields", "practicable degree plans", "diverse instructional methods", "strict teacher certification" and "networking". At meantime, there is a "confused professional boundary" about early childhood education at the U.S. higher schools, which has some negative influences on training early childhood teachers. We consider that "preschool education" is more suitable than "early childhood education" as a major paralleled with "elementary education", "secondary education" and "higher education" at higher schools.
\end{abstract}

Key words: early childhood education; preschool education; teacher education; higher schools; United States of America (U.S.A.). 


\section{Introduction}

Teacher education includes pre-service and in-service training, and early childhood education at higher schools is the main aspect of early childhood teacher education. Early childhood education ${ }^{1}$ at higher schools is a type of education to train the early childhood teachers for children 0-8 years old and has developed very quickly and made great progress in the United States of America (U.S.A.).

At present, more and more researchers have paid attention to issues about early childhood teacher education of the U.S., and they have mainly involved in its developmental history, features and trends (Yang, 2006; Wang, 2008, pp. 8-11; Li, 2011; Blank, 2010; Yang \& He, 2013); educational aims or quality requirements (Cao, Wang, Tian \& Shmizu, 2013; Bueno, Darling-Hammond \& Gonzales, 2010; Mevorach \& Miron, 2011; Ganey, 2010; Romeyn, 2010; Kim \& Kemple, 2011; Xie \& Lu, 2008), curricular (Kim, 2013; LoCasale-Crouch et al., 2011), methods (Androutsos, 2014; Chapman, 2014; Conroy, Sutherland, Vo, Carr \& Ogston, 2014; Curenton \& Zucker, 2013; Souto-Manning \& Biglan, Layton, Jones, Hankins \& Rusby, 2013; Weigel, Weiser, Bales \& Moyses, 2012; Singh, Lancioni, Winton, Karazsia \& Singh, 2013; Heisner \& Lederberg, 2011; Ji, 2011; Dunst, Trivette \& Deal, 2011; Mead \& Carey, 2011, p. 3; Mitchell, 2010; Tal, 2010; Bayat, 2010; Morris, Raver, Millenky, Jones \& Lloyd, 2010); reflections on the training programmes (Saracho, 2013; Chen \& McCray, 2012; Fults \& Harry, 2012; Piasta et al., 2012; Kim, Chang \& Kim, 2011; Pelletier, 2010; Wang \& Ding, 2010) and strategies (Rivkin, 2014; Whitebook at al., 2012, p. 27; Bridges, Fuller, Huang \& Hamre, 2011; Abbate-Vaughn, Paugh \& Douglass, 2011; Pianta, 2011; Nicholson \& Reifel, 2011; Guo, Justice, Sawyer \& Tompkins, 2011; Lasser \& Fite, 2011; Arslan, 2010). However, there are still few studies analyzing the developmental status of early childhood education at the U.S. higher schools. The purpose of the paper is mainly to introduce the status and features of early childhood education at the U.S. higher schools in order to provide some experiences for the other countries.

\section{Historical context on early childhood education at the U.S. higher schools}

Early childhood teacher education in the United States has a long history and rich experiences. Without early childhood normal school, early childhood teacher education has at present changed from directed normal education to non-directed normal education in the United States; and the history is roughly divided into the normal school period ( $18^{\text {th }}$ century to the end of the $19^{\text {th }}$ century), the normal college period (end of the

\footnotetext{
"Preschool education" means a type of education for 0-5 or 6 years old children in the paper.
} 
$19^{\text {th }}$ century to the middle of the $20^{\text {th }}$ century) and the normal university period (Yang \& He, 2013; Li, 2011; Blank, 2010; Wang, 2008, pp 8-11; Yang, 2006).

\subsection{Normal school's period ( $18^{\text {th }}$ century - end of the $19^{\text {th }}$ century)}

In the $19^{\text {th }}$ century, Froebel kindergarten was introduced into the United States and not paid too much attention because there was then no example for a woman and teacher to be provided college level training, and early childhood teacher were trained by means of Apprenticeship Training. In the period, preschool education in the United States had changed from nursery schools into the charity kindergartens into public kindergartens; during the 1820s - 1830s, some secondary normal schools were established, where enrolled in the graduates in primary school (eight-year), trained about 1-4 years and mainly provided general education and teacher certification. In 1868, Elizabeth Pebody (1804-1894) set up the first preschool normal school in Boston; and in 1874, the Department of Preschool Teacher Training was established at the City College of New York and provided young women with pre-service training with preschool education courses such as "Theory of Froebel", "Game", "Music" and "Art", etc.; and in 1880, Eudora Hailman established the first pre-school teacher training constitution "Wisconsin State Normal School". During the 1880s - 1890s, there were eight preschool normal schools with the "Infant observation" course and made the preschool teachers learn the "Methodology of Kindergarten".

\subsection{Normal college's period (late $19^{\text {th }}$ century - middle of the $20^{\text {th }}$ century)}

Before and after the first world war, kindergartens had already been attached to primary schools in the United States, and higher normal colleges have gradually trained teachers at all levels, mainly enrolled the graduates from senior high schools, and there are few teachers with a four-year bachelor degree. Before the World War II, early childhood teachers were mainly trained at normal colleges with 250 in 1948, and the number of preschool normal schools had decreased from 325 in 1919 to 60 in 1947.

\subsection{Normal university's period (after the middle of the $20^{\text {th }}$ century)}

Since the middle of the $20^{\text {th }}$ century, due to national policies and guidance, the United States have further reformed and improved the training modes of early childhood teachers and established a high starting point, complete system and an operative early childhood teacher education system. After the World War II, more and more normal colleges had gradually been expanded into comprehensive universities or subsumed 
into comprehensive universities, and early childhood teachers had mainly been trained at the Department of Education of Arts and Sciences Colleges and the College of Education of the Comprehensive University. On the one hand, preschool normal schools were gradually disappeared, and there are less and less normal colleges. There was no preschool normal school, and there were 100 normal colleges in the 1960s, however, there were only 7 normal colleges in 1980s. On the other hand, there were stricter requirements for enrollments qualifications, academic years and educational levels for early childhood teachers. For example, after 1970, the grade points of the teachers applicants GPA should be more than 2 or 2.5 (out of 4), and after 10 years, academic years of the teacher applicants were extended to 4 or 5 years, early childhood teachers had to at least earn an associate degree (most with a bachelor's degree), and succeed in the training programs of professional accreditation and gotten "early childhood teaching certificate" or "elementary school teacher's certificate" (usually dominated by early teacher certification). At present, there are at least 228 higher schools with early childhood education major in the United States ${ }^{2}$.

In summary, the United States had more than 150-year developmental history and has at present set up an open, professional, diverse and high-quality system in early childhood teacher education.

\section{Developmental status of early childhood education at the U.S. higher schools}

In order to understand the developmental status of early childhood education at the U.S. higher schools, we mainly analyze the total status, professional focuses, curricular system, graduation requirements and career options of early childhood education majors at 228 U.S. higher schools.

\subsection{Total status}

Investigation tells us that there are at least 228 higher schools with early childhood education and four-level degrees including 210 colleges or universities with undergraduate programs, 162 with master programs, 78 with doctor programs and 33 with specialists in the United States; at the meantime, there are more colleges and universities in the

2 We mainly investigate the status on early childhood education majors in 170 best universities with education, 201 best comprehensive universities and 180 best arts and sciences colleges in 2014 (Retrieved from http:// www.coe.uga.edu/academics/degrees/eds; http://usa.bailitop.com/ranking/20130111/20053.html; http:// www.zinch.cn/top/university/367584/2014/367595; http://usa.bailitop.com/ranking/20121031/16561.html.) 
Middle Atlantic, Upper Mississippi (Great Lakes) and South East than the Rocky Mountain state, New England and the Pacific (see table 1).

Table 1

Number and distribution of early childhood education in USA higher schools

\begin{tabular}{|l|c|c|c|c|c|c|}
\hline Districts & $\begin{array}{c}\text { Number } \\
\text { of States }\end{array}$ & $\begin{array}{c}\text { Number } \\
\text { of Universities }\end{array}$ & $\begin{array}{c}\text { Number } \\
\text { of Bachelor }\end{array}$ & $\begin{array}{c}\text { Number } \\
\text { of Master }\end{array}$ & $\begin{array}{c}\text { Number } \\
\text { of Doctor }\end{array}$ & $\begin{array}{c}\text { Number } \\
\text { of Specialists }\end{array}$ \\
\hline New England & 6 & 14 & 12 & $12(2)$ & 4 & 1 \\
\hline Middle Atlantic & 8 & 62 & 51 & $41(11)$ & 14 & 4 \\
\hline South East & 4 & 27 & 27 & 17 & 9 & 6 \\
\hline South & 6 & 19 & 19 & 16 & 11 & 6 \\
\hline Mid-west & 8 & 20 & 20 & 16 & 10 & 6 \\
\hline $\begin{array}{l}\text { Upper Mississippi } \\
\text { (Great Lakes) }\end{array}$ & 5 & 40 & 39 & $22(1)$ & 10 & 6 \\
\hline $\begin{array}{l}\text { Rocky Mountain } \\
\text { state }\end{array}$ & 6 & 10 & 10 & 10 & 8 & 2 \\
\hline Pacific & 5 & 17 & 13 & $13(4)$ & 4 & 2 \\
\hline South-west & 3 & 18 & 18 & 15 & 8 & 0 \\
\hline Total & 52 & 227 & 209 & $162(18)$ & 78 & 33 \\
\hline
\end{tabular}

Especially, the Education Specialist or Specialist in Education (EdS) are an advanced terminal degree in the United States that are designed for individuals who wish to develop advanced knowledge and theory beyond the master's degree level, but may not wish to pursue a degree at the doctoral level and provide the necessary background and professional expertise for students planning to go into university teaching, supervisory or leadership roles in post secondary schools, curriculum planning, consultant work, or similar positions.

\subsection{Professional focuses}

Investigation shows us that instruction and research on early childhood education at 228 U.S. colleges and universities with the early childhood education major mainly focus on some fields or issues such as "early childhood education" (birth - Grades three), "early childhood and special education", "early childhood and elementary education", "early childhood and middle childhood education", "early childhood and child development", "early childhood and family", "early childhood and languages education", "early intervention", etc. (see table 2). 
Table 2

Focuses and its frequencies of early childhood education major in USA higher schools

\begin{tabular}{|c|c|c|c|c|c|c|}
\hline Educational & \multicolumn{2}{|c|}{ Bachelor } & \multicolumn{2}{|c|}{ Master } & \multicolumn{2}{|c|}{ Doctor } \\
\hline $\begin{array}{l}\text { Focuses } \\
\text { and frequencies }\end{array}$ & $\begin{array}{l}(1) \\
(2) \\
(3) \\
(4) \\
(5) \\
(6) \\
(7) \\
(8) \\
(9) \\
(10) \\
(11) \\
(12) \\
(13) \\
(14) \\
(15) \\
(16) \\
(17) \\
(18)\end{array}$ & $\begin{array}{l}\text { Early childhood education } \\
\text { (preschool) (141); } \\
\text { Early childhood special } \\
\text { education (43); } \\
\text { Birth-grade 3 (Prek-grade 3, } \\
\text { P-grad 3) (29); } \\
\text { Grade 4-12 (24); } \\
\text { Child development (26); } \\
\text { Primary or elementary } \\
\text { education (19); } \\
\text { (Middle) childhood } \\
\text { education (11); } \\
\text { Family (10); } \\
\text { (Dual) language or bilingual } \\
\text { education (6); } \\
\text { Early intervention (6); } \\
\text { Science education } \\
\text { (mathematics) (4); } \\
\text { Multicultural education (2); } \\
\text { Society (2); } \\
\text { Arts and physical education } \\
\text { (2); } \\
\text { Interdisciplinary early } \\
\text { childhood education (1); } \\
\text { Technology education (1); } \\
\text { Play (0); } \\
\text { Child psychology (0). }\end{array}$ & $\begin{array}{l}(1) \\
(2) \\
(3) \\
(4) \\
(5) \\
(6) \\
(7) \\
(8) \\
(9) \\
(10) \\
(11) \\
(12) \\
(13) \\
(14) \\
(15) \\
(16) \\
(17) \\
(18)\end{array}$ & $\begin{array}{l}\text { Early childhood education } \\
\text { (preschool) (130); } \\
\text { Early childhood special } \\
\text { education (53); } \\
\text { Primary or elementary } \\
\text { education (18); } \\
\text { (Middle) childhood } \\
\text { education (15); } \\
\text { Birth-grade 3 (Prek-grade 3, } \\
\text { P-grad 3) (13); } \\
\text { Grade 4-12 (7); } \\
\text { Child development (9); } \\
\text { Family (5); } \\
\text { (Dual) language or bilingual } \\
\text { education (4); } \\
\text { Early intervention (7); } \\
\text { Interdisciplinary early } \\
\text { childhood education (4); } \\
\text { Science education (1); } \\
\text { Multicultural education (1); } \\
\text { Arts education (1); } \\
\text { Child psychology (1); } \\
\text { Society (1); } \\
\text { Play (1); } \\
\text { Technology education (0). }\end{array}$ & $\begin{array}{l}(1) \\
(2) \\
(3) \\
(4) \\
(5) \\
(6) \\
(7) \\
(8) \\
(9) \\
(10) \\
(11) \\
(12) \\
(13) \\
(14) \\
(15) \\
(16) \\
(17) \\
(18)\end{array}$ & $\begin{array}{l}\text { Early childhood education } \\
\text { (preschool) (40); } \\
\text { Early childhood special } \\
\text { education (11); } \\
\text { (Middle) childhood } \\
\text { education (4); } \\
\text { Family (3); } \\
\text { Child development (3); } \\
\text { Birth-grade 3 ( PreK-Grad 3, } \\
\text { P-Grad 3) (2); } \\
\text { Primary or elementary } \\
\text { education (2); } \\
\text { Society (2); } \\
\text { Early intervention (2); } \\
\text { (Dual) language education } \\
\text { (1); } \\
\text { Child psychology (1); } \\
\text { Interdisciplinary early } \\
\text { childhood education (1); } \\
\text { Multicultural education (1); } \\
\text { Play (1); } \\
\text { Grade 4-12 (0); } \\
\text { Arts education (0); } \\
\text { Science education (0); } \\
\text { Technology education (0). }\end{array}$ \\
\hline
\end{tabular}

In addition, "interdisciplinary early childhood education", "play" and "child psychology" are in some degree strengthened in graduate education of some higher schools.

\subsection{Curricular system}

About the curricular systems of early childhood education at the U.S. universities, there are mainly "vertical" and "horizontal" modes, the former directly introduces the curricula according to the academic years, and the latter does the curricula according to different 
classification standards. It is true that curricula are usually divided into different types at different U.S. higher schools.

Curricula for the bachelor at the U.S. higher schools are mainly divided into two types such as "General Educational Requirements" and "Core Professional Requirements" at the University of New Mexico3; three types such as "General Courses", "Major Courses" and "Elective Courses" at the Wittenberg University"; four types such as "General Studies Requirements", "Required Studies in Psychology", "Required Studies in Mathematics" and "Required Studies in Education" at the Saint Vincent Colleges; and five types or more than five types such as include "Social Contexts of Early Childhood Education", "Critical Perspectives in Early Childhood Education", "Global, Comparative Early Childhood", "Major Theorists in Early Childhood", "Early Childhood Education Programs", "Theories of Curriculum for Prekindergarten and Kindergarten ", "Parents and Education", "Play \& Early Development" and "Early Childhood Education Program Development" at the University of Texas at Austin'.

Curricula for the master of early childhood education at the U.S. higher schools are mainly divided into two types such as "Required Courses" (3 credits each) and "Approved Electives" (Choose Three Courses, nine credits total) at the George Mason University"; three types such as "Required Core Courses", "Professional Area" and "Specialty Area" at the East Carolina University8; four types such as "Core Requirements", "Specialization Requirements", "Exit Examination/Final Project" and "Thesis" at the he Ohio State University"; and five or more than five types such as "Critical Perspectives on Childhood Education", "Early Childhood Education Programs", "Early Childhood Teacher Education", "Inquiry in Play", "Parents and Education", "Research Seminar", "Social Construction of Thinking in Childhood", "Social Contexts of Childhood Education" and "Theories of Childhood" at the University of Texas at Austin ${ }^{10}$.

Curricula for the doctor degree at the U.S. higher schools are usually divided into three types such as "College of Education Professional Core", "C \& I Professional Core" and "Early Childhood Specialty Area" at the Southern Illinois University"; four types such as "Research Methods and Tools", "Required Concentration Courses", "CELS Professional Development Courses" and "Dissertation" at the University of South Florida'2; and

3 Retrieved from http://coe.unm.edu/departments/programs/bachelors-degrees.html

4 Retrieved from http://www.wittenberg.edu/academics/education/requirements.html

5 Retrieved from http://www.stvincent.edu/Majors_and_Programs/Majors_and_Programs/Education/ Education_K-12/

6 Retrieved from http://www.edb.utexas.edu/education/departments/undergrad/

7 Retrieved from http://cehd.gmu.edu/academics/master

8 Retrieved from http://catalog.ecu.edu/content.php?catoid=3\&navoid=186

9 Retrieved from http://tl.ehe.osu.edu/academic-programs

10 Retrieved from http://education.oregonstate.edu/academics

11 Retrieved from http://gradschool.siu.edu/academics/curriculum-instruction.html

12 Retrieved from http://www.coedu.usf.edu/main/programs.html 
mainly five or more than five types such as "Core Classes", "Specialty Area", "Research Methodology", "Research Internships" and "Dissertation Research" at the University of Alabama at Birmingham ${ }^{13}$.

Curricula of early childhood education specialist are mainly divided into "major", "foundation" and "elective" curricular at the Indiana University"i; and "educational theory and curriculum and methods" courses in major areas such as language and literacy, mathematics, science and social studies and "research-based course" where they design and carry out projects in elementary classrooms at the University of Georgia" ${ }^{15}$.

\subsection{Graduation requirements}

There are a lot of specific requirements for degree or teacher certification of early childhood education major at the U.S. higher schools. For example, the bachelor degree of early childhood at the Wittenberg University needs satisfactory completion of all the general courses requirements, and the major courses 51 hours plus 14 hours in related areas and additional electives to meet graduation requirement of 130 semester hours ${ }^{16}$; the master degree of early childhood education at the Florida International University requires all the students to take 15 hours of foundation courses in curriculum and instruction and in methods/statistics, the students take an additional 18 hours within early childhood education/development, and 3 hours of education-related electives ${ }^{17}$; the specialist in early childhood education at the Florida State University will be equipped with "Research", "Theory Base for Childhood Education", "Evaluation”, "Curriculum", "Instruction", "Special Field Experience", "Practicums" and "Directed Research"18; and the students awarded a Ph.D. of Education including early childhood education at the George Mason University must satisfactorily complete all the courses listed on the student's approved program of doctoral study, have at least a B average on all the coursework included in the program of study, satisfactorily complete a comprehensive portfolio assessment and an accepted dissertation and the oral defence of this dissertation (CEHD, 2012, p. 9).

\footnotetext{
13 Retrieved from http://www.uab.edu/education/home/future-students/degrees-programs

${ }_{14}$ Retrieved from http://www.coe.uga.edu/academics/graduate

15 Retrieved from http://education.indiana.edu/graduate/programs/index.html

16 Retrieved from http://www5.wittenberg.edu/academics/education/requirements.html.

17 Retrieved from http://education.fiu.edu/masters_degrees.html?expanddiv=ms 13 .

18 Retrieved from http://www.coe.fsu.edu/Current-Students/Departments/School-of-Teacher-Education-STE/ Current-Students/Early-Childhood-Education/Specialist.
} 


\subsection{Career options}

Early childhood education at the U.S. higher schools usually provides the students with some specific career options for the future. For example, opportunities for bachelor degree of "infant through early childhood education" at the Barry University include "classroom teacher (Grades K-3)", "preschool teacher (Infancy - Prekindergarten)", "advocate for an early childhood readiness coalition" and "museum educator with an art, science or children's museum" ${ }^{\prime 19}$; career opportunities of the master of early childhood education at the Monmouth College include pre-school teacher at private schools, pre-school teacher at public schools, P-3 teacher at public school, early intervention specialist, head start coordinator and parent educator ${ }^{20}$; and "The Child Development/ Early Childhood Education Ph.D." at the University of Nebraska - Lincoln provides students with rigorous education, research, and teaching experiences that will prepare them as professionals qualified to work at universities, in private research firms, and public policy institutions ${ }^{21}$.

From above all, the early childhood education major at the U.S. higher schools has not only made a great progress in number and educational level, but also has specific and operatable training plans.

\section{Features of early childhood education at the U.S. higher schools}

According to the history and status, we consider that early childhood education at the U.S. higher schools has developed very quickly and focused on "the higher educational level", "various major fields", "practicable degree plans", "diverse instructional methods", "strict teacher certification" and "networking".

\subsection{Higher educational level}

"High-level" means that early childhood education teacher training including training institutions, students, curriculum, education levels and other aspects and non-directional preschool teacher training system in the United States, are non-direction, diverse and high-level in modes, curriculum, and teacher certification (Wang, 2008, pp. 13-14) and has paid attention to multicultural awareness and inclusive education ability of the teachers; and high-quality and social justice are its value-orientation (Yang \& He, 2013;

\footnotetext{
19 Retrieved from http://www.barry.edu/education-undergraduate/about/infancy-early-childhood.html.

20 Retrieved from http://www.monmouth.edu/.

21 Retrieved from http://cehs.unl.edu/cyaf/programs/child-developmentearly-childhood-education-phd.
} 
Peng, 2008). Investigation shows that there are no secondary preschool normal school, and pre-service training of the early childhood teachers are mainly done at graduate schools, colleges of early childhood education, Colleges of Human Development, 2-year community colleges, 4-year colleges and universities, and there are more bachelors than associate bachelors and masters; and $71 \%$ higher schools with master degrees, $34.2 \%$ with doctor and $14.5 \%$ with education specialist degrees at 228 U.S. universities. In fact, the state pre-k programs with higher teacher qualification requirements improve children's school readiness so the states get the most out of their investment in early education, and educators with at least a bachelor's degree coupled with specialized training in early childhood are best able to foster the development of the cognitive, social and emotional skills children need to be ready for kindergarten (Bueno, DarlingHammond \& Gonzales, 2010).

\subsection{Various major fields}

At the U.S. higher schools, early childhood education is usually divided into different fields and attaches importance to individual differences of the early childhood teachers. For example, undergraduate education of early childhood education at the Wittenberg University involves "Early Childhood (P-3)", "Middle Childhood (4-9)", "Early childhood (P-3)" and "Intervention Specialist" of "Mild/Moderate Educational Needs (K-12)", "Early Childhood Generalist (4-5)", "Middle Childhood Generalist (4-6)"22; the master of early childhood education at the University of Massachusetts Amherst includes "Child Study and Early Education", "Early Intervention (0-3 years)", "Early Childhood Education (0-5 years)", "Family Services", "Public Policy for Children and Families", and "Interdisciplinary Work in Childhood Studies"23; and the doctorate program of early childhood and childhood education at the New York University involves in "Human and Child Development", "Social Contexts of Learning", "The Influence of Culture on Teaching and Learning", "Multiple Ways of Knowing,","Families as Partners in Children's Schooling", "The Uses of Evaluation and Assessment in Teaching and Learning," "The Impact of Language and Literacy Development on Children's Learning" and "Curriculum Development" ${ }^{\text {"24 At }}$ meantime, some universities in the United States pay more attention to interdisciplinary research of "Early childhood education", especially between early childhood education and special education/elementary education/child development/educational leadership/family education, etc. For example, there is a major of "Interdisciplinary Early Childhood Education (IECE)" for the bachelor, master and doctor degrees at the University of Kentucky"25; and "Early Childhood Education" at the Montana State University involves

\footnotetext{
${ }^{22}$ Retrieved from http://www5.wittenberg.edu/.

${ }^{23}$ Retrieved from http://www.umass.edu/.

${ }^{24}$ Retrieved from http://steinhardt.nyu.edu/.

25 Retrieved from http://www.uky.edu/.
} 
"Child Development", “Developmentally Appropriate Practices", “Early Intervention with Children with Special Needs", and "Assessment and Intervention, Advocacy, and Program Administration" 26 . All the different fields do not only train wide learning and research interests of the early childhood education students but also meet the various needs of preschool education of individuals and society.

\subsection{Practicable degree plans}

The early childhood teacher education programmes at the U.S. higher schools usually consist of recruitment and selection, general education, professional foundations, instructional knowledge, field experiences and clinical practice, and programme evaluation (Saracho, 2013). Pre-service trainings for kindergarten teachers pay more attention to widely general knowledge, knowledge on pedagogy and psychology, children's ages and related teaching methods, the influence and guidance of preschool teachers' skills, and practical ability; and in-service trainings think much of professional, studentbased, kindergarten-based and "higher-quality" (Yan, 2008, pp. 31-36). For example, the program overview of the bachelor of "Infancy Through Early Childhood Education (Birth - $3^{\text {rd }}$ Grade)" at the Barry University introduces "who will I teach", "what will I learn" and "where can I teach"27; master program of "early childhood education" at the Lesley University shows the meaning, features and outcomes of learning ${ }^{28}$; and the doctor degree of early childhood education at the University of Houston includes "Is this Program for Me", "What will I learn" and "What can I do with my degree"29. Thus, the degree plans are usually easy to be operated and practiced.

\subsection{Diverse methods}

Early childhood education at the U.S. higher schools thinks much of not only operativity of the degree plan but also diversity of training methods including discussion, speech and debate in classrooms; communication out of school; and online. For example, based on the six competency goals, the Child Development Associate (CDA) training program provides three different types of the training patterns about Center-Based, Family Child Care and Home Visitor and a candidate can earn his CDA credential through the CDA Professional Preparation Program or local college training and direct assessment (Ji, 2011); a multi-year action research study paid particular attention to the process whereby an early childhood teacher investigated, problematized, and challenged the

\footnotetext{
26 Retrieved from http://www.montana.edu/.

27 Retrieved from http://www.barry.edu/education-undergraduate/about/infancy-early-childhood.html.

28 Retrieved from http://www.lesley.edu/early-childhood-education/

29 Retrieved from http://www.coe.uh.edu/academic-departments/cuin/
} 
nature of curriculum and practices in a diverse preschool classroom and can foster culturally-relevant teaching and shifting early childhood teachers' perceptions of what it means to engage in culturally-relevant teaching, respecting and honoring cultural diversities (Souto-Manning \& Mitchell, 2010); pre-service early childhood educators presented with the PulpMotion created an anchored instructional video where experiences were shown to have a marked increase of on-line discussion board postings and reviews of "non-required" reading of early childhood special education (Chapman, 2014); three types of workshops (half day/full day or multi-day) or one of two types of onsite, field-based training (basic and enhanced) of in-service training could improve early intervention practitioners' abilities to use family-systems intervention practices (Dunst, Trivette \& Deal, 2011); and the journals and video-recording could promote self-conscious productive reflections and clarify content knowledge and link theory to practice (Bayat, 2010).

\subsection{Strict teacher certification}

Strict professional standards are designed to promote the professional development and enhance the quality of early childhood teachers. On the one hand, the nation and states have thought much of improving standards of early childhood teachers. National Association for the Education of Young Children (NAEYC) Amendment in 2003 published a new standard which stressed preschool teachers in the $21^{\text {st }}$ century should have "knowledge" and "skills" about how to promote the children's development and learning, establishing a harmonic relationship between family and the community, observation records and evaluation, teaching and learning, and become the experts and the new standard of NAEYC in 2004 focused on linguistic and cultural diversity, integration of children with special needs among ordinary children, subject knowledge, supervised living communities, assessing children's learning and development, teaching strategies and ways to promote children's development and learning standards and learning experience (Xie \& Lu, 2008).

On the other hand, there have been strict programs for teacher certification at the U.S. higher schools. In the past ten years, the U.S. higher schools have paid much attention to the preschool teacher education reform so as to promote teachers' professional development and improve the quality of preschool education, and the initial teacher training reform laid emphasis on cultivating students' practice ability, and in-service teacher training is aimed at improving teachers' professional level (Cao, Wang, Tian \& Shmizu, 2013). At present, there are some certification departments and standards for early childhood teachers at the U.S. colleges and universities. For example, "OAR584018-0115 Early Childhood Education Authorization" from "14-15-early childhood-hand- 
book in Lewis and Clark College" introduces five specific standards of preschool teacher in Oregon in the following (p. 12) ${ }^{30}$.

\subsection{Networking}

The Internet may be a practical alternative for providing high-quality, research-based training, information, and resources to these professionals (Weigel, Weiser, Bales \& Moyses, 2012). Distance education is a planned learning experience or a method of instruction characterized by quasi-permanent separation of the instructor and learner, and has been used as a method of the pre-service teacher preparation and an in-service training to fulfil a mandate to upgrade the knowledge/skills/qualifications of teaching abilities; and includes correspondence model, audio-based models, televisual models, computer-based multimedia models, web-based models and mobile models (Burns, 2011, pp. 9-10). There are rich internet resources about early childhood education major at the U.S. higher schools such as online courses, online learning, distance education, continuing education and adult education, and the learners will not only easily get their net information and resources but also apply for online degrees. For example, there are online bachelor and master degrees at the University of North Carolina at Chapel $\mathrm{Hill}^{31}$; and doctor and educational specialists degrees at the the University of Alabama ${ }^{32}$.

All in all, early-childhood teacher education at the U.S. colleges and universities has experienced 140 years, been one of the most developed countries with rich experiences, and formed its own characteristics.

\section{Problems on early childhood education at the U.S. higher schools}

Although early childhood education at the U.S. higher schools has made great progress, we consider that the main disadvantage is "confused professional boundary ", which is shown in the following.

1. "Elementary education" includes "early childhood education", and there is no independent "Early childhood education" major at some higher schools. For example, "Elementary education" at the University of Wisconsin includes "Early Childhood/ English as a Second Language", "Middle Childhood - Early Adolescence/English as a Second Language”,"Middle Childhood - Early Adolescence/Special Education”and

\footnotetext{
30 Retrieved from http://graduate.lclark.edu/live/files/17429-14-15-ecel-handbook-finalpdf.

31 Retrieved from http://www.unc.edu/academics/.

32 Retrieved from http://bamabydistance.ua.edu/degrees/.
} 
"Middle Childhood - Early Adolescence/Content-Focused Minor"33; the Elementary Teacher Preparation Program at the Duke University prepares candidates for critical thinking and decision making that will be required of them as caring and reflective educators in K-6 classrooms ${ }^{34}$; the master's Degree of Early Childhood Education Specialization within the Elementary Education at the Indiana University is designed for individuals who have completed a degree in early childhood education or elementary education and who have a teaching license in early childhood education (preschool), elementary/primary grades (K-3), or elementary education $(\mathrm{K}-6)^{35}$.

2. "Childhood education" includes "early childhood education", and there is no independent "early childhood education" major at some higher schools. The master programs childhood education at the Ripon College are of the early childhood/middle childhood level (grades PK through 5) and the middle childhood/early adolescence level (grades 1 through 8) ${ }^{36}$; the School of Education at the University of North Carolina at Chapel Hill offers three undergraduate programs in teacher education such as "Middle Grades Education (Grades 6-9)"," "Elementary Education (Kindergarten Grade 6)" and "Child Development and Family Studies (Birth - Kindergarten)", which is grounded in the disciplines of "Child Development", "Early Childhood Education" and "early childhood special education" ${ }^{37}$.

3. "Early childhood education" parallels with "elementary education" or "childhood education" at some higher schools. For example, the "Elementary and Kindergarten Education" major offers teaching options in "Early Childhood Education" and in "Elementary Education" at the Pennsylvania State University - University Park where "Childhood and Early Adolescent Education" has met all of the requirements for "the PK-4", "English Education 4-8"or "Social Studies Education 4-8"38; the master of "Early Childhood/Elementary Education" at the Rutgers University is intended for certified teachers who wish to continue their study of learning and teaching in early childhood/elementary settings s $^{39}$; and "Early Childhood and Childhood Education" at the State University of New York at Buffalo deals with children from preschool up to the middle school years; and the students may choose to emphasize early

33 Retrieved from http://pubs.wisc.edu/ug/education_Outlines_ElemEd.htm.

34 Retrieved from http://educationprogram.duke.edu/teacherpreparation/elementary.

35 Retrieved from http://education.indiana.edu/graduate/programs/early-childhood/Early\%20Childhood\%20 Ed\%20 Master\%20Info.pdf

36 Retrieved from http://www.ripon.edu/education/.

37 Retrieved from http://soe.unc.edu/academics/cdfs/.

38 Retrieved from http://bulletins.psu.edu/undergrad/campuses/details/26/.

39 Retrieved from http://gse.rutgers.edu/academic-programs/edm-programs/early-childhoodelementaryeducation. 
childhood (birth - grade 2), childhood teaching (grades 1-6), or both, or a specific childhood curriculum field, such as literacy or mathematics ${ }^{40}$.

Reflecting above problems, we consider that the main reason lies in "confused professional boundary" of "Early Childhood Education" for the children with 0-8 years old as a major at higher schools. In fact, "Early Childhood Education" is not only a part of "Childhood Education" ${ }^{14}$ but also involves in "Preschool Education" (0-5 or 6 years old) and "Elementary Education" (5 or 6-12 years old), which usually causes some problems and difficulties such as aims, curricula, method, and evaluation of teaching and learning in colleges and universities.

\section{Conclusion}

In conclusion, the United States is one of the best developed countries in early childhood teacher education and has accumulated a lot of experiences and formed some features in early childhood education major at the higher schools. As to the other countries, it is very necessary to learn from early childhood education at the U.S. higher schools.

In addition, we consider that it may be more reasonable to make "early childhood education" a parallel research field with "middle childhood education" and "advanced childhood education" or "adolescent education" than as a major paralleled with "elementary education", "secondary education" and "higher education" at the higher schools; and we consider that it is better to make "preschool education" a parallel major with "elementary education", "secondary education" and "higher education" than "early childhood education" at the higher schools. Only like that, "preschool teacher education" and "elementary teacher education" will have more specific and pertinent purposes, curricula and methods, which means the "preschool education" major at the higher schools will train teachers at nurseries and kindergartens and "elementary education" is to train teachers at elementary schools or primary schools.

${ }^{40}$ Retrieved from http://grad.buffalo.edu/Academics/academic_programs.html?CFC_target= FWtuWCmzf92 jBKOWxkYiOjhG3g-http\%3A\%2F\%2Fwww.gradmit.buffalo.edu\% 2Fgrad\%2Facademics\%2Facademicprog rams2.asp\%3Fid\%3D34

${ }^{41}$ "Childhood Education" may be divided into "Early Childhood Education", "Middle Childhood Education" and "Advanced Childhood Education" or "Adolescent Education". 


\section{Acknowledgement}

This research is supported in funding by the China Scholarship Council and the Association of Philosophy and Social Science of Sichuan Province in PRC, and we would like to thanks to them.

\section{References}

Abbate-Vaughn, J., Paugh, P. C. \& Douglass, A. (2011). Sound bites won't prepare the next generation: Early childhood teacher education Policy public-private divide in Massachusetts. Educational Policy, 25(1): 215-239.

Androutsos, O. (2014). Designing and implementing teachers' training sessions in a kindergartenbased, family-involved intervention to prevent obesity in early childhood. The ToyBox-study. Obesity Reviews, 15 (Suppl. 3): 48-52.

Arslan, E. (2010). Analysis of communication skill and interpersonal problem solving in preschool trainees. Social Behavior and Personality: An International Journal, 38(4): 523-530.

Bayat, M. (2010). Use of dialogue journals and video-recording in early childhood teacher education. Journal of Early Childhood Teacher Education, 31(2): 159-172.

Biglan, A., Layton, G. L., Jones, L. B., Hankins, M. \& Rusby, J. C. (2013). The value of workshops on psychological flexibility for early childhood special education staff. Topics in Early Childhood Special Education, 32(4): 196-210.

Blank, J. (2010). Early Childhood Teacher Education: Historical Themes and Contemporary Issues. Journal of Early Childhood Teacher Education, 31(4): 391-405.

Bridges, M., Fuller, B., Huang, D. S. \& Hamre, B. K. (2011). Strengthening the early childhood workforce: How wage incentives may boost training and job stability. Early Education and Development, 22(6): 1009-1029.

Bueno, M., Darling-Hammond, L. \& Gonzales, D. (2010). A matter of degrees: Preparing teachers for the Pre-K classroom. Education reform series. [on-line] retrieved from: http://www. pewstates.org.

Cao, N. X., Wang, Y. L., Tian, J. \& Shmizu, M. (2013). On the preschool teacher education reform in the US, UK and Japan in recent 10 years. Primary \& Secondary Schooling Abroad, (7): 1-7.

Chapman, D. N. J. (2014). Using PulpMotion videos as instructional anchors for pre-service teachers learning about early childhood special education. International Research in Early Childhood Education, 5(1): 56-63.

Chen, J. Q. \& McCray, J. (2012). The what, how, and why of effective teacher professional development in early mathematics education. NHSA Dialog: A Research-to-Practice Journal for the Early Childhood Field, 15(1): 113-121.

College of Education and Human Development (CEHD, 2012). Program guidelines Ph.D. in education program of George Mason University [Web log message]. [on-line] retrieved from http://gse. gmu.edu/phd-in-education/program-structure.

Conroy, M. A., Sutherland, K. S., Vo, A. K., Carr, S. \& Ogston, P. L. (2014). Early childhood teachers' use of effective instructional practices and the collateral effects on young children's behavior. Journal of Positive Behavior Interventions, 16(2): 81-92.

Curenton, S. M. \& Zucker, T. (2013). Instructional conversations in early childhood classrooms: Policy suggestions for curriculum standards and professional development. Creative Education, 4(7A1): 60-68. 
Dunst, C. J., Trivette, C. M. \& Deal, A. G. (2011). Effects of in-service training on early intervention practitioners' use of family-systems intervention practices in the USA. Professional Development in Education, 37(2): 181-196.

Fults, R. M. \& Harry, B. (2012). Combining family centeredness and diversity in early childhood teacher training programs. Teacher Education and Special Education, 35(1): 27-248.

Ganey, T. L. (2010). The relationship between prekindergarten teachers' self-reported beliefs and practices about literacy instruction and their preschool's kindergarten readiness rate. [on-line] retrieved from http://www.proquest.com/en-US/products/dissertations/ individuals.shtml.

Guo, Y., Justice, L. M., Sawyer, B. \& Tompkins, V. (2011). Exploring factors related to preschool teachers' self-efficacy. Teaching and Teacher Education, (27): 961-968.

Heisner, M. J. \& Lederberg, A. R. (2011). The impact of child development associate training on the beliefs and practices of preschool teachers. Early Childhood Research Quarterly, (26): 227-236.

Ji, J. (2011). On the Child Development Associate Training Program and Its inspiration. Studies in Preschool Education, (5): 25-29.

Kim, H. K. \& Kemple, K. M. (2011). Is music an active developmental tool or simply a supplement? Early childhood preservice teachers' beliefs about music. Journal of Early Childhood Teacher Education, 32(2): 135-147.

Kim, J. (2013). Confronting invisibility: Early childhood pre-service teachers' beliefs toward homeless children. Early Childhood Education Journal, (41): 161-169.

Kim, S., Chang, M. D. \& Kim, H. (2011). Does teacher educational training help the early math skills of English language learners in Head Start? Children and Youth Services Review, (33): 732-740.

Lasser, J. \& Fite, K. (2011). Universal preschool's promise: Success in early childhood and beyond. Early Childhood Education Journal, (39): 169-173.

$\mathrm{Li}, \mathrm{X}$. Y. (2011). Retrospect and revelations on exploration of pre-service training system of American preschool teacher. Journal of Inner Mongolia Finance and Economics College, (6): 135-139.

LoCasale-Crouch, J., et al. (2011). Implementing an early childhood professional development course across 10 Sites and 15 sections: Lessons learned. NHSA Dialog: A Research-to-Practice Journal for the Early Childhood Field, 14(4): 275-292.

Mevorach, M. \& Miron, M. (2011). Experienced early childhood teachers as graduate students: A process of change. Early Childhood Education Journal, 39(1): 7-16.

Mead, S. \& Carey, K. (2011). Beyond bachelor's: The case for charter colleges of early childhood education. [on-line] retrieved from http://www.brookings.edu.

Morris, P., Raver, C. C., Millenky, M., Jones, S. \& Lloyd, C. M. (2010). Making preschool more productive how classroom management training can help teachers. New York: MDRC.

Nicholson, S. \& Reifel, S. (2011). Sink or swim: Child care teachers' perceptions of entry training experiences. Journal of Early Childhood Teacher Education, 32(1): 5-25.

Pelletier, P. C. (2010). Prekindergarten programs requiring a bachelor degree to ensure readiness for kindergarten: A correlational study. [on-line] retrieved from: http://www.proquest.com/ en-US/products/dissertations/individuals.shtml.

Peng, P. (2008). Analysis on the contemporary development of preschool teacher education training in some different coutries. The Science Education Article Collects, (11): 12-19.

Piasta, S. B., et al. (2012). Impact of professional development on preschool teachers' conversational responsivity and children's linguistic productivity and complexity. Early Childhood Research Quarterly, (27): 387-400.

Pianta, R. C. (2011). Teaching children well: New evidence-based approaches to teacher professional development and training. [on-line] retrieved from: http://files.eric.ed.gov/fulltext/ ED535637.pdf.

Rivkin, K. (2014). Reggio Emilia-Inspired Programs in the United States: What does "Inspired" really mean? [unpublished master dissertation]. San Diego: State University. 
Romeyn, R. (2010). A descriptive-comparative study of professional development and observed quality in early care and education programs. [on-line] retrieved from: http://www.proquest. com/en-US/products/dissertations/individuals.shtml.

Saracho, O. N. (2013). Early childhood teacher preparation programmes in the USA. Early Child Development and Care, 183(5): 571-588.

Singh, N. N., Lancioni, G. E., Winton, A. S. W., Karazsia, B. T. \& Singh, J. (2013). Mindfulness training for teachers changes the behavior of their preschool students. Research in Human Development, 10(3): 211-233.

Souto-Manning, M. \& Mitchell, C. H. (2010). The role of action research in fostering culturally-responsive practices in a preschool classroom. Early Childhood Education Journal, 37(4): 269-277.

Tal, C. (2010). Case studies to deepen understanding and enhance classroom management skills in preschool teacher training. Early Childhood Education Journal, 38(2): 143-52.

Wang, S. N. (2008). Research on pre-service training for preschool teacher in USA [Unpublished master dissertation]. Sichuan Normal University, PRC.

Wang, X. L. \& Ding, B. P. (2010). On the training of early childhood teachers in America. Studies in Preschool Education, (10): 49-54.

Weigel, D. J., Weiser, D. A., Bales, D. W. \& Moyses, K. J. (2012). Identifying online preferences and needs of early childhood professionals. Early childhood research \& practice, 14(2): 2-13.

Whitebook, M., etc. (2012). By default or by design? Variations in higher education programs for early care and teachers and their implications for research methodology, policy, and practice. Berkeley, CA: Center for the Study of Child Care Employment, University of California.

Xie, Q \& Lu, Z. J. (2008). New trends and enlighenments of professional training for preschool teachers in USA. Data of Culture and Education, (6): 95-96.

Yan, M. L. (2008). Exploring on ideas of preschool teacher in modern USA [Unpublished master dissertation]. Northeast Normal University, PRC.

Yang, H. L. (2006). Origin and development and reform of foreign early childhood teacher education in the 20th century. Journal of Huanggang Normal University, (2): 47-53.

Yang, X. Q. \& He, K. C. (2013). American early childhood pre-service teacher education: History, reality and future. Comparative Education Review, (2): 9-16.

\section{Contact:}

Mgr. Shangwei Li

Institute of Rural Preschool Education, Yibin University

Yibin, PRC, 644007

E-mail: 1967shangwei@163.com 